\title{
Safety aspects of ultrasound in prenatal diagnosis
}

\author{
Sicherheitsaspekte des Ultraschalls in der Pränataldiagnostik
}

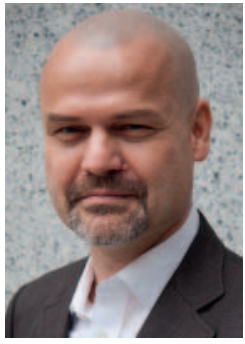

PD Dr. Kai-Sven Heling

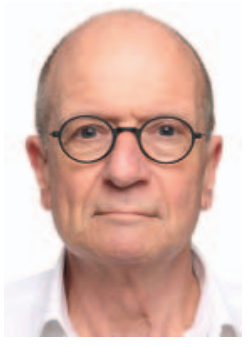

Prof. Dr. Peter Kozlowski
Correspondence

PD Dr. Kai-Sven Heling

Pränataldiagnostik, Friedrichstraße 147, 10117 Berlin

heling@feindiagnostik.de

Prof. Dr. Peter Kozlowski

praenatal.de, Graf-Adolf-Straße 35, 40210 Düsseldorf

kozlowski@praenatal.de

Bibliography

DOI https://doi.org/10.1055/a-1104-3412

Published online: 2020

Ultraschall in Med 2020; 41: 116-119

(c) Georg Thieme Verlag KG, Stuttgart · New York

ISSN 0172-4614
Ultrasound was used for the first time in pregnancy in the $1960 \mathrm{~s}$ and then found broader clinical application in the $70 \mathrm{~s}$ and particularly in the $80 \mathrm{~s}$, thereby revolutionizing obstetrics and ultimately resulting in the development of a new subspecialty: prenatal diagnosis and perinatal medicine. This means that ultrasound has been used for more than 40 years in pregnancy to examine fetuses. This development was facilitated on the one hand by the ease of use of the method and the resulting broad availability and on the other hand by the fact that ultrasound is an imaging method that does not require the use of physical radiation. This resulted in early differentiation from diagnostic radiology (classic abdominal X-ray, pelvic X-ray, amniofetography) and later also from computed tomography. Magnetic resonance imaging (MRI) has the potential to supplement ultrasound for targeted issues but is still very cost-intensive and has numerous limitations.

Despite this success story, concerns regarding the safety of ultrasound in prenatal diagnosis have arisen again in 2020. Why? What happened?

Ultrasound - mechanical vibrations in a medium (mechanical waves) - was designated as non-ionizing radiation in recent years. The term radiation induces anxiety in many pregnant women. Biological effects of mechanical waves (non-ionizing radiation ultrasound) are dependent on threshold values, while biological effects of electromagnetic waves (X-ray radiation, gamma radiation) are always present regardless of threshold values.

A regulation regarding the use of non-ionizing radiation for non-medical purposes was also recently enacted in Germany. Although it primarily does not apply to prenatal diagnosis, § 10 states: "Use of ultrasound in a pregnant person. Fetal exposure must be avoided when using ultrasound for non-medical purposes" [1].

This wording has caused renewed uncertainty among both pregnant women and physicians. A huge response was seen on the Internet and on social media. The general sentiment was: "ultrasound is dangerous".

This needs to be addressed, especially since our patients have a right to scientifically proven information. We as physicians have a responsibility to ensure our patients receive correct information. In its courses, the German Society for Ultrasound in Medicine (DEGUM) teaches the corresponding technical principles of diagnostic ultrasound. Every physician performing prenatal diagnosis is familiar with technical parameters like acoustic output, frame rate $(\mathrm{Hz})$, probe frequency, pulse repetition frequency (PRF), and much more. Is the same also true for other technical indices, such as the thermal index ( $\mathrm{TI}$ ) and mechanical index, and their meaning $[2,3]$ ?

This issue of the journal includes a study by Drukker et al. [4] regarding safety indices in ultrasound and discusses whether we as examiners observe the recommendations of the professional societies and what we focus on in the ultrasound image. The authors analyzed 637 complete ultrasound examinations from the first, second, and third trimester of pregnancy performed by 17 different examiners (sonographers and physicians). Automatic analysis of the complete ultrasound examination was coupled with examiner eye-tracking and the values for MI (mechanical index), Tls (thermal index for soft tissue), and TIb (thermal index for bone) and the particular ultrasound mode were extracted. The lowest $\mathrm{TI}$ values were measured in B-mode imaging (highest value: 0.8 ), while the highest TI values were measured during pulsed Doppler ultrasound (3.0). All time limits were maintained. Eyetracking analysis showed that attention was paid to bioeffect safety indices in only 27 of 637 ultrasound examinations (4.2\%). What can we learn from this study?

All examiners were aware of and observed the relevant time limit for a particular examination. The TI value data (mechanical 
index doesn't really play a role in prenatal diagnosis) shows that the average TIb values in $\mathrm{B}$-mode imaging are very low $(0.14$ $( \pm 0.01)$ in the first trimester, $0.15( \pm 0.01)$ in the second trimester and $0.14( \pm 0.01)$ in the third trimester). In the case of color Doppler, the values are slightly higher $(0.62,0.53$ and 0.52$)$. They are highest in pulsed Doppler (1.65 in the first trimester, 1.67 in the second trimester, and 1.89 in the third trimester), with peak values of up to 3.0 being achieved. According to the recommendations published by the American Institute of Ultrasound in Medicine, the British Medical Ultrasound Society and the EFSUMB, the TI should ideally be less than 0.7 [5-9]. Theoretically, ultrasound could then be performed without time limits, which of course would not actually happen in practice (ALARA principle). If this limit value is exceeded, the exposure time should be limited: $A$ maximum of 60 minutes for a TI of up to 1.0 , less than 15 minutes for a $\mathrm{Tl}$ of up to 2.0 and less than one minute for a TI of up to 3.0. The present study shows that such values can be reached during pulsed Doppler. However, they do not need to be reached! Ultrasound examiners can program their presets so that a lower acoustic output is generally used. There is no loss of quality and the TI values remain under 0.7 even in pulsed Doppler, especially since the maximum acoustic output is only in effect while Doppler is activated, i. e., for the time it takes to display a single Doppler curve on the monitor, which is less than 10 seconds. However, the majority of examiners did not pay any attention to these indices!

Therefore, the present study effectively shows that it is time for us reevaluate - but not because ultrasound is dangerous. Rather we need to take the fears and concerns of patients seriously. This includes how the method is performed. Every ultrasound examiner needs to know which technical parameters can be changed and how. Examiners should know where the corresponding parameters are displayed on the screen. Of course, the parameters do not require constant monitoring if an optimal preset has been set but should be closely monitored if the preset parameters are changed. Peak TI values of $>1.0$ can be avoided and are not necessary to achieve good image quality. Manufacturers should not even provide such options for ultrasound examination in pregnancy. This is particularly true for the first trimester in which the indication for pulsed Doppler ultrasound should generally be determined on a very strict basis. If there is an indication, the TI values should be $<0.7$.

More than half of the examiners in the study had less than 5 years of professional experience. There was no differentiation between physicians and sonographers.

The mechanical index plays virtually no role in prenatal diagnosis since the fetus is completely surrounded by fluid in the uterus and is not subjected to contrast agents or air bubbles. Therefore, there are no cavitation nuclei and no cavitation effects can occur.

The classic ultrasound methods are used in prenatal diagnosis: B-mode, color Doppler, pulsed Doppler, and volume ultrasound. The highest acoustic output (TI) is achieved in pulsed Doppler. A reduction of the acoustic output decreases the $\mathrm{TI}$ to less than 0.7 so that the value remains under the threshold. Potentiation of biological thermal effects is not possible since these are threshold values [6].
Compared to other modes, volume ultrasound subjects the fetus to a very low thermal load. This is due to the significantly longer time intervals between scan procedures.

The literature does not include a single study reporting a risk to the fetus as a result of ultrasound. This relates to the repeatedly investigated effect on fetal brain development (autism spectrum disorders) as well as the development of left-handedness or secondary effects in fetal organs [10-16]. The theoretically possible temperature increase at the examination site when using pulsed Doppler ultrasound can be counteracted with corresponding knowledge (reduction of the acoustic output). However, it must be stated that, when using modern devices, this theoretical effect is currently lower than temperature increases caused by physical activity or fever [1].

According to all current recommendations, ultrasound is a safe and risk-free method for prenatal diagnosis. According to the international recommendations of the AIUM, BMUS and EFSUMB, thermal index ( $\mathrm{TI}$ ) limit values should be taken into consideration. If the $\mathrm{Tl}$ is less than 0.7 as recommended, there is no time limit for the examination. If this limit value is exceeded (in the case of pulsed Doppler if ever), the examination time decreases. However, the minute that is allowed at a $\mathrm{Tl}$ of 3.0 is not even reached in practice. In any case, knowledge of these effects, the ability to influence these parameters, and the location of this information is important. Manufacturers as well as professional societies and users of the method can make a contribution here.

\section{Sicherheitsaspekte des Ultraschalls in der Pränataldiagnostik}

Nachdem Ultraschall in der Schwangerschaft erstmals in den 1960 er-Jahren erfolgte, kam es in den 70er- und insbesondere 80er-Jahren zu einer breiten klinischen Anwendung des Ultraschalls, die die damalige Geburtshilfe revolutioniert und letztlich entscheidend zu einer Entwicklung einer neuen Subspezialisierung geführt hat: der Pränataldiagnostik und der Perinatalmedizin. Dies bedeutet eine mehr als 40-jährige Anwendung von Ultraschall in der Schwangerschaft zur Untersuchung des Fötus. Diese Entwicklung wurde zum einen durch die einfache Anwendbarkeit der Methode und die damit verbundene weite Verbreitung und zum anderen durch die Tatsache, dass Ultraschall ein bildgebendes Verfahren ohne Verwendung von physikalischen Strahlen ist, begünstigt. Dies führte frühzeitig zur Abgrenzung zur Röntgendiagnostik (klassische Abdomen-Übersicht, Beckenröntgen, Amniofetografie) und später auch zur Computertomografie. Die Magnetresonanztomografie (MRT)-Diagnostik hat das Potenzial zur Ergänzung der Ultraschalldiagnostik bei gezielten Fragestellungen, ist jedoch immer noch sehr aufwendig und hat doch viele Limitationen.

Trotz dieser Erfolgsstory stellt sich nun im Jahr 2020 wieder einmal die Frage nach Sicherheitsaspekten des Ultraschalls in der Pränataldiagnostik. Warum? Was ist geschehen?

So wurde in den letzten Jahren Ultraschall - also an Materie gebundene mechanische Schwingungen (mechanische Wellen) - als nichtionisierende Strahlung bezeichnet. Der Begriff Strahlung ruft bei vielen Schwangeren Ängste hervor. Biologische 
Effekte von mechanischen Wellen (nichtionisierende Strahlung Ultraschall) sind an Schwellenwerte gebunden, biologische Effekte von elektromagnetischen Wellen (Röntgenstrahlung, Gammastrahlung) hingegen sind schwellenwertunabhängig immer vorhanden.

Zum anderen wurde jüngst in Deutschland eine Verordnung zur Anwendung nichtionisierender Strahlung zu nichtmedizinischen Zwecken in Kraft gesetzt. Dies hat primär nichts mit Pränataldiagnostik zu tun, allerdings lautet der entsprechende $\S 10$ : „Anwendung von Ultraschall an einer schwangeren Person. Bei der Anwendung zu nichtmedizinischen Zwecken darf ein Fötus nicht exponiert werden." [1].

Diese Formulierung hat erneut zu erheblichen Unsicherheiten bei Schwangeren und Ärzten zugleich geführt. Durch das Internet und soziale Medien ist ein erhebliches Medienecho entstanden. Der allgemeine Tenor lautete: „Ultraschall ist gefährlich“.

Es erscheint sinnvoll, sich mit diesen Aspekten zu beschäftigen, zumal unsere Patientinnen ein Recht auf wissenschaftlich fundierte Antworten haben. Diese Aufgabe liegt bei uns Ärztinnen und Ärzten. Die Deutsche Gesellschaft für Ultraschall in der Medizin (DEGUM) vermittelt in ihrem Kurssystem die entsprechenden technischen Grundlagen zum diagnostischen Ultraschall. Jedem Arzt und jeder Ärztin der Pränataldiagnostik sind technische Parameter wie Acoustic output, Bildfolgerate $(\mathrm{Hz})$, Frequenz des Schallkopfs, Pulse repetition frequency (PRF) und vieles mehr ein Begriff. Ist dies bei anderen technischen Indizes, wie zum Beispiel thermischer Index (TI) oder mechanischer Index, und deren Bedeutung auch so [2, 3]?

In diesem Heft erscheint eine Arbeit von Drukker et al. [4] zu Sicherheitsindizes im Ultraschall und der Frage, ob wir uns als Untersucher an die Empfehlungen der Fachgesellschaften halten und worauf wir im Ultraschallbild unsere Aufmerksamkeit richten. Die Autoren analysierten 637 komplette Ultraschalluntersuchungen aus dem ersten, zweiten und dritten Trimenon der Schwangerschaft, die von 17 verschiedenen Untersuchern (Sonografer und Ärzte) durchgeführt wurden. Die automatische Analyse der kompletten Ultraschalluntersuchung wurde mit einem Eye-Tracking des Untersuchers gekoppelt und die jeweiligen Werte für MI (mechanischer Index), TIs (thermischer Index für Weichteilgewebe) und TIb (thermischer Index für Knochen) und der jeweilige Ultraschallmodus wurden extrahiert. Es wurde festgestellt, dass die niedrigsten TI-Werte im B-Bild gemessen wurden (höchster Wert 0,8 ), die höchsten TI-Werte wurden bei der gepulsten Dopplersonografie gemessen $(3,0)$. Die Zeitlimits wurden jeweils eingehalten. Die Analyse des Eye-Trackings ergab, dass nur bei 27 von 637 Ultraschalluntersuchungen (4,2\%) auf die Bioeffekt-Sicherheitsindizes geachtet wurde. Was kann man aus dieser Arbeit herausnehmen?

Das Bewusstsein für ein entsprechendes Zeitlimit einer Untersuchung ist vorhanden, die Begrenzung wird von allen Untersuchern eingehalten. Betrachtet man hingegen die Daten zu den TI-Werten (der mechanische Index spielt in der Pränataldiagnostik eher keine Rolle), so fällt auf, dass die Mittelwerte des TIb im BBild mit 0,14 $( \pm 0,01)$ im ersten Trimenon, 0,15 $( \pm 0,01)$ im zweiten Trimenon und 0,14 $( \pm 0,01)$ im dritten Trimenon sehr niedrig sind. Beim Farbdoppler sind die Werte etwas höher $(0,62,0,53$ und 0,52$)$, am höchsten sind sie beim gepulsten Doppler (1,65 im ersten Trimenon, 1,67 im zweiten Trimenon und 1,89 im dritten Trimenon), jedoch wurden hier Spitzenwerte von bis zu 3,0 erreicht. Die Amerikanische und Britische Ultraschallgesellschaft sowie die EFSUMB haben Empfehlungen herausgegeben, nach denen der TI am besten unter 0,7 liegen sollte [5-9]. Theoretisch könnte man dann zeitlich unbegrenzt Ultraschall durchführen, was natürlich in der Praxis nicht stattfindet (ALARA-Prinzip). Kommt es zu einer Überschreitung dieses Grenzwertes, so sollte die Expositionszeit limitiert werden: bis zu einem TI von 1,0 maximal 60 Minuten, bis zu einem TI von 2,0 weniger als 15 Minuten und bis zu einem TI von 3,0 weniger als 1 Minute. Die vorliegende Arbeit zeigt, dass solche Werte im Rahmen des gepulsten Dopplers erreicht werden können. Aber sie müssen nicht erreicht werden! Wer sich als Untersucher mit seinem Ultraschallgerät beschäftigt, kann seine Voreinstellungen (Preset) derart programmieren, dass man generell mit einer geringeren Sendeleistung (Acoustic output) arbeitet. Es ist keine qualitative Einbuße im Bild zu verzeichnen und auch im gepulsten Doppler bleiben die TI-Werte $<0,7$ ! Zumal beim gepulsten Doppler die maximale Sendeleistung nur bei Aktivierung des Dopplers aktiviert ist, d. h. für einen Durchlauf der Dopplerkurve auf dem Monitor von weniger als 10 Sekunden. Genau auf diese Indizes hat jedoch die überwiegende Mehrzahl der Untersucher gar nicht geachtet!

Die vorliegende Arbeit zeigt also sehr gut, dass wir einmal mehr selbstkritisch sein müssen. Nicht im Sinne, dass Ultraschall gefährlich ist. Aber wir müssen die Ängste und Sorgen der Patientinnen ernst nehmen. Und dazu gehört die Beschäftigung mit der Technik. Jeder Untersucher und jede Untersucherin im Ultraschall sollten wissen, welcher technische Parameter sich wie verändern lässt. Man sollte auch wissen, wo die entsprechenden Parameter auf dem Bildschirm angezeigt werden. Bei Einstellung eines optimalen Presets ist dies sicher nicht ständig notwendig, aber jedoch bei entsprechenden Änderungen von Parametern des Presets. Spitzenwerte des TI von >1,0 sind vermeidbar und schon gar nicht notwendig für ein qualitativ gutes Bild. Hier ist durchaus auch die Industrie gefordert, solche Möglichkeiten für die Ultraschalluntersuchung in der Schwangerschaft erst gar nicht zu eröffnen. Dies gilt natürlich besonders für das erste Trimenon, in dem generell die Indikation zur Durchführung einer gepulsten Dopplersonografie sehr eng gefasst werden sollte. Und falls diese besteht, so sollten die Werte des $\mathrm{TI}<0,7$ liegen.

Mehr als die Hälfte der Untersucher in der Studie hatte weniger als 5 Jahre Berufserfahrung. Es wurden keine Unterschiede zwischen Ärzten und Sonografern gemacht.

Der mechanische Index spielt in der Pränataldiagnostik praktisch keine Rolle, da der Fötus innerhalb des Uterus komplett von Flüssigkeit umgeben ist und weder Kontrastmitteln noch luftgefüllten Bereichen ausgesetzt ist. Es fehlen also Kavitationskeime, insofern können keine Kavitationseffekte auftreten.

In der Pränataldiagnostik werden die klassischen Ultraschallverfahren eingesetzt: B-Bild, Farbdoppler, gepulster Doppler und die Volumensonografie. Die höchste Sendeleistung (TI) wird dabei beim gepulsten Doppler erreicht. Eine Reduktion der Sendeleistung verringert den TI kleiner als 0,7, sodass man unterhalb der Schwelle bleibt. Eine Potenzierung biologischer thermischer Effekte ist nicht möglich, es handelt sich hier um Schwellenwerte [6]. 
Die Volumensonografie hat im Vergleich mit den anderen Modi nur eine sehr geringe thermische Belastung für den Fötus. Ursache für diese besonders geringe Schallexposition sind die deutlich längeren zeitlichen Intervalle zwischen jeweils 2 Abtastvorgängen.

Betrachtet man die Literatur aus den vergangenen Jahren, so findet man keine Studie, die über einen Hinweis für eine Gefährdung des Fötus durch Ultraschall berichtet. Dies betrifft sowohl die immer wieder angeführte Beeinflussung der Hirnentwicklung des Fötus (Autism spectrum disorders), als auch die Entwicklung von Linkshändigkeit oder sekundäre Effekte in fetalen Organen [10-16]. Der theoretisch möglichen Temperaturerhöhung am Untersuchungsort bei Anwendung der gepulsten Dopplersonografie kann man durch entsprechende Kenntnis entgegenwirken (Reduktion der Sendeleistung). Wobei man auch sagen muss, dass dieser theoretische Effekt heute mit den modernen Geräten deutlich unter dem Bereich einer Temperaturerhöhung durch körperliche Aktivität oder bei Fieber liegt [1]!

Die Anwendung von Ultraschall in der Pränataldiagnostik stellt nach allen gängigen Empfehlungen ein sicheres und risikoloses Verfahren dar. Entsprechend den internationalen Empfehlungen von AIUM, BMUS und EFSUMB sollten Grenzwerte des thermischen Index (TI) berücksichtig werden. Es wird empfohlen, dass der TI kleiner als 0,7 liegt, dann hat man grundsätzlich keine zeitliche Beschränkung der Untersuchung. Überschreitet man diesen Grenzwert (wenn überhaupt dann bei gepulstem Doppler), so reduziert sich die Untersuchungszeit, wobei die selbst bei einem TI von 3,0 mögliche Minute in der Praxis nicht erreicht wird. Wichtig ist auf jeden Fall die Kenntnis dieser Effekte, die Möglichkeit der Beeinflussung dieser Parameter und das Wissen darüber, wo man diese Informationen findet. Einen Beitrag hierzu können sowohl die Industrie als auch wir als wissenschaftliche Fachgesellschaften und Anwender der Methode leisten.

\section{Conflict of Interest}

The authors declare that they have no conflict of interest.

\section{References}

[1] Heling KS, Kozlowski P, Dudwiesus H. Neue Strahlenschutzverordnung Ultraschall in der Schwangerschaft ist gefährlich? Eine nicht haltbare Feststellung. Ultraschall in Med 2019; 40: 266-268

[2] Marsal K. The output display standard: has it missed its target? Ultrasound Obstet Gynecol 2005; 25: 211-214

[3] Deane C, Lees C. Doppler obstetric ultrasound: a graphical display of temporal changes in safety indices. Ultrasound Obstet Gynecol 2000; 15: $418-423$

[4] Drukker L, Droste R, Chatelain P et al. Safety Indices of Ultrasound: Adherence to Recommendations and Awareness During Routine Obstetric Ultrasound Scanning. Ultraschall in Med 2020; 41: 1-8

[5] American Institute of Ultrasound in Medicine. Official Statement: Recommended Maximum Scanning Times for Displayed Thermal Index (TI) Values 2016. https://www.aium.org/officialStatements/65 (May 2, 2019)

[6] Safety Group of the British Medical Ultrasound Society. Guidelines for the safe use of diagnostic ultrasound equipment 2009. https://www. bmus.org/static/uploads/resources/BMUS-Safety-Guidelines-2009-revi sion-

FINAL-Nov-2009.pdf (Accessed May 2nd 2019)

[7] Helmy S, Bader $\mathrm{Y}$, Koch $\mathrm{M}$ et al. Measurement of Thermal Effects of Doppler Ultrasound: An In Vitro Study. PLoS ONE 2015; 10: e0135717. doi:10.1371/journal.pone.0135717

[8] Kollmann C, Jenderka KV, Moran CM et al. EFSUMB Clinical Safety Statement for Diagnostic. Ultrasound - (2019 revision). Ultrasound in Med 2019. doi:10.1055/a-1010-6018

[9] Duggan PM, Liggins GC, Barnett SB. Ultrasonic heating of the brain of the fetal sheep in utero. Ultrasound Med Biol 1995; 21: 553-560

[10] Abramowicz JS. Ultrasound and autism: association, link, or coincidence? J Ultrasound Med 2012; 31: 1261-1269

[11] Hoglund Carlsson L, Saltvedt S, Anderlid BM et al. Prenatal ultrasound and childhood autism: long -term follow-up after randomized controlled trial of first vs. second-trimester ultrasound. Ultrasound Obstet Gynecol 2016; 48: 285-288

[12] ISUOG Statement on ultrasound exposure in the first trimester and autism spectrum disorders 2016.

[13] EFSUMB Statement on the Safe Use of Doppler Ultrasound at 11-14 Weeks (or Earlier in Pregnancy) 2018.

[14] EFSUMB response to published study of the relationship between ultrasound exposure in the first trimester and the severity of autism spectrum disorders 2016.

[15] Paul RosmanN, Vassar R, Doros G et al. JAMA Pediatr 2018; 172: 336344. doi:10.1001/jamapediatrics.2017.563

[16] Ang ES, Gluncic V, Duque A et al. Prenatal exposure to ultrasound waves impacts neuronal migration in mice. Proc Natl Acad Sci USA 2006; 103: 12903-12910. Epub 2006 Aug 10 